\title{
SUBSTANTIATION OF EFFECTIVE INSTRUMENTS OF REGULATION OF FINANCIAL IMBALANCES OF ENDOGENOUS- ORIENTED DEVELOPMENT OF THE REGIONS OF UKRAINE
}

\author{
TARAS KLOBA, SOLOMIIA KLOBA
}

\begin{abstract}
The article deals with instruments recommended for regulating financial imbalances of endogenous-oriented development of the regions of Ukraine as an integral part of the regional economy management mechanism, and also explored the ways of regulating regional socioeconomic processes in crisis conditions. The basic principles of selection of instruments for the regulation of financial imbalances of endogenous-oriented development of regions are determined. The classification of instruments of regulation of financial imbalances of endogenous-oriented development is considered. The basic tools used to support the development of regions and municipalities are analyzed: legal; related to the development of appropriate strategies and programs; based on the implementation of inter-municipal cooperation; financial. The three main directions of financial imbalance regulation tools for endogenous-oriented development of the regions are investigated, which are used to analyze the impact on the effectiveness of regional development at different stages of the economic cycle. The system of specially organized measures of regulation of financial imbalances of endogenously oriented development of regions is substantiated. In modern conditions, great attention is paid to the problems of regulation of financial imbalances of endogenously oriented development of regions of Ukraine, the implementation of which requires special instruments. A holistic presentation of the systemic mechanism of regulation of financial imbalances of endogenously oriented development of regions is offered. After all, ensuring endogenous-oriented development of regions in the current conditions of functioning of the economy of Ukraine requires the implementation of strategies of socioeconomic transformation, which will be aimed at changing the financial imbalances of development of regions and mechanisms for their implementation. Endogenously oriented regional development means increasing the level of overcoming adverse social, economic and environmental risks and trends, with the ability of regions to provide financial imbalances, selfregulation, self-improvement with maximum use of internal as well as external borrowing resources to meet the needs of the population of the regions. The endogenous-oriented development of the regions is conditioned by the identification of instruments for regulating the financial imbalances of the regions and the identification of conditions for their achievement, which are derivatives for ensuring the endogenously-oriented development of the regions as a whole.
\end{abstract}

Keywords: basic principles of selection of regulatory instruments, financial imbalance regulation instruments, classification of regulatory instruments, basic directions of regulatory instruments. 


\section{INTRODUCTION}

Regulation of financial imbalances of endogenous-oriented regional development is an integral part of the overall process of reforming Ukraine's economy, which necessitates the necessity to justify the proportions of rational participation of the regions in financial support and development of the regional economy.

For Ukraine in the context of large-scale transformations of the domestic economy, modernization of endogenous-oriented development of regions is a key task of development. Deep differentiation of macroeconomic parameters of the regions of modern Ukraine has become one of the main characteristics of its economy, which inevitably leads to an increase in the number of problem areas. The task of reducing the level of negative consequences of the lag in socioeconomic development necessitates the improvement of regulation of financial imbalances of endogenous-oriented development of the regions of Ukraine.

Currently, there is a change in the paradigm of regional economic development and regional policy, the search for ways to improve the effectiveness of territorial development, management, new forms, methods and mechanisms of participation of regional authorities in managing the territory [1].

Research on the problems of regulation tools of financial imbalances of endogenous-oriented development of regions such Ukrainian scientists as O. Anchishkin, P. Belyenki, Z. Vernal, I. Vakhovich, V. Geets, Z. Gerasymchuk, A. Golykova, B. Danylyshyn, M. Dolyshny, S. Doroguntsov, P. Zhuk, S. Zludko, L. Kowalska, V. Kravtsiv, I. Lukinov, V. Mamonova, I. Mikhasyuk, V. Rudenko, M. I. Skripnichenko, D. Stechenko, I. Storonyanskaya, M. Chumachenko, V. Shevchuk and others. However, comprehensive research in this area is under-researched and needs further study.

The policy of regulation of financial imbalances of endogenously oriented development of regions is realized with the help of a certain set of tools. Proper selection and successful application of methods and tools of the mechanism of regulation of endogenously-oriented development of the regions of Ukraine in practice will allow to reach a high level of their sustainable development. A rational approach in the construction of incentive instruments will lead to the maximum socioeconomic effect.

\section{RESULtS}

The intensity of the use of certain regulatory instruments applied in the framework of the policy of regulation of financial imbalances of endogenously oriented development of the regions depends on the extent to which the spheres of life of the regions are developed and their relations are coordinated. Thus, in order to achieve a high level of balance in the sustainable development of the regions, IE to support the interconnection, integrity and dynamic balance of social, economic and environmental components, it is necessary to use tax and transfer incentive instruments. First of all, this is due to the fact that budgets and fiscal stimulus instruments are closely interconnected and actively applied in all areas of activity of the region. In addition, their use involves the redistribution of funds through the budgets of different levels, which helps to achieve social justice, economic growth and environmental equilibrium, thus contributing to the harm ony, balance and equilibrium of the sustainable development of the region.

Thus, instruments of regulation of financial imbalances of endogenously-oriented development of regions mean a set of forms, methods and methods of influence on processes of development of territories by the state bodies for the achievement of certain goals. In this case, the regulatory instruments are the specification of the rules and regulations that form the institutions of regulation (management).

The tools for regulating the financial imbalances of endogenously oriented regional development must be based on certain grounds, namely the selection of incentive measures, that is, the principles of selection of incentive instruments.

The basic principles of selection of instruments for the regulation of financial imbalances of endogenously oriented development of regions are the following, which are shown in Figure 1. 


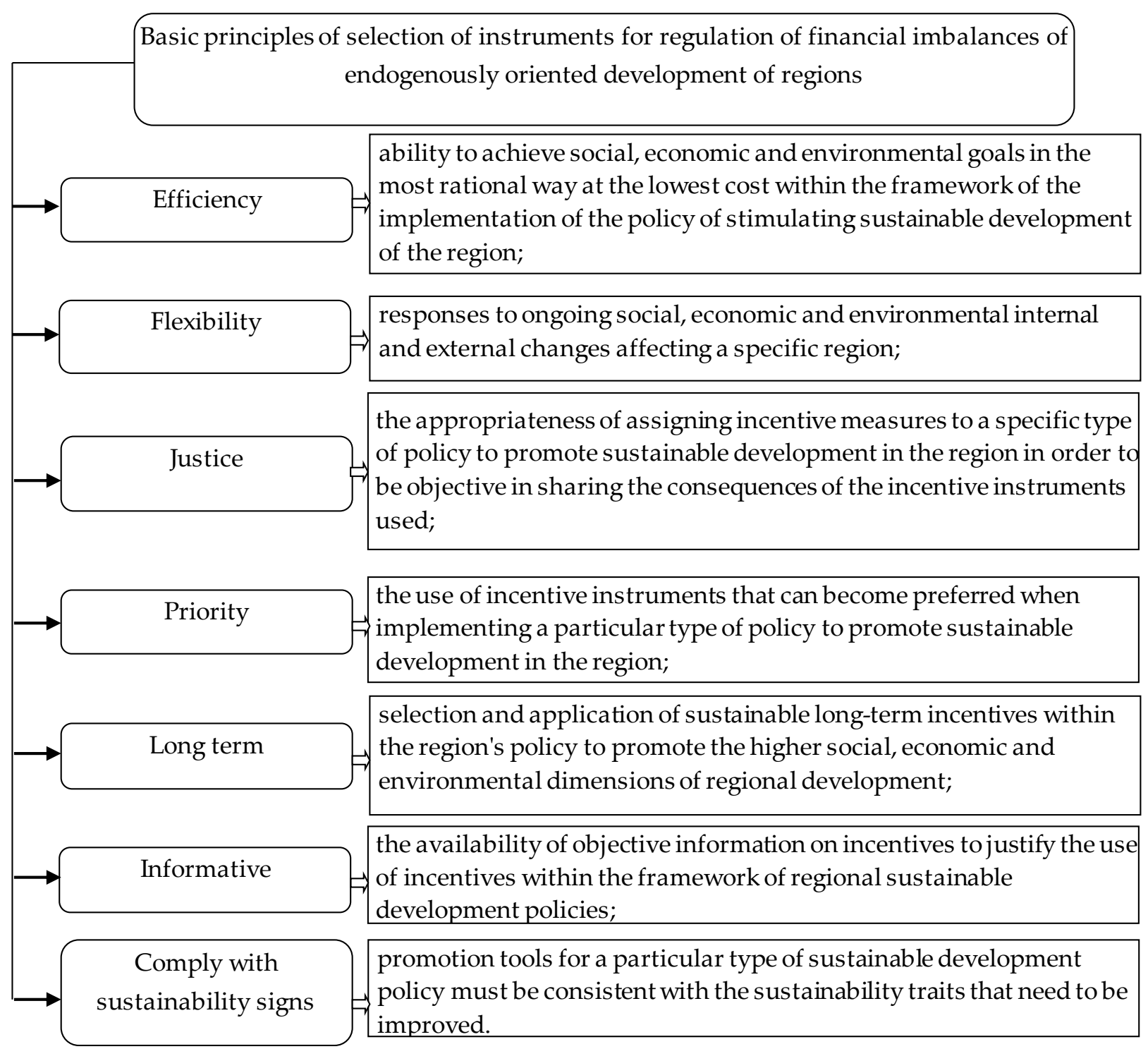

Fig. 1. Basic principles of selection of instruments for the regulation of financial imbalances of endogenously oriented development of regions. Source: is based on [2; 3]

The tools of regulation of financial imbalances of endogenously oriented development of regions are tools of activating influence on financial imbalances which are aimed at ensuring achievement of endogenous oriented development of the region through active activity of state and regional authorities.

The set of relevant institutions and instruments constitutes an economic mechanism of regulation.

To date, numerous classifications of instruments for regulating financial imbalances in endogenously-oriented development are known (Figure 2). 


\section{Classification of instruments for regulation of financial imbalances of endogenously} oriented development

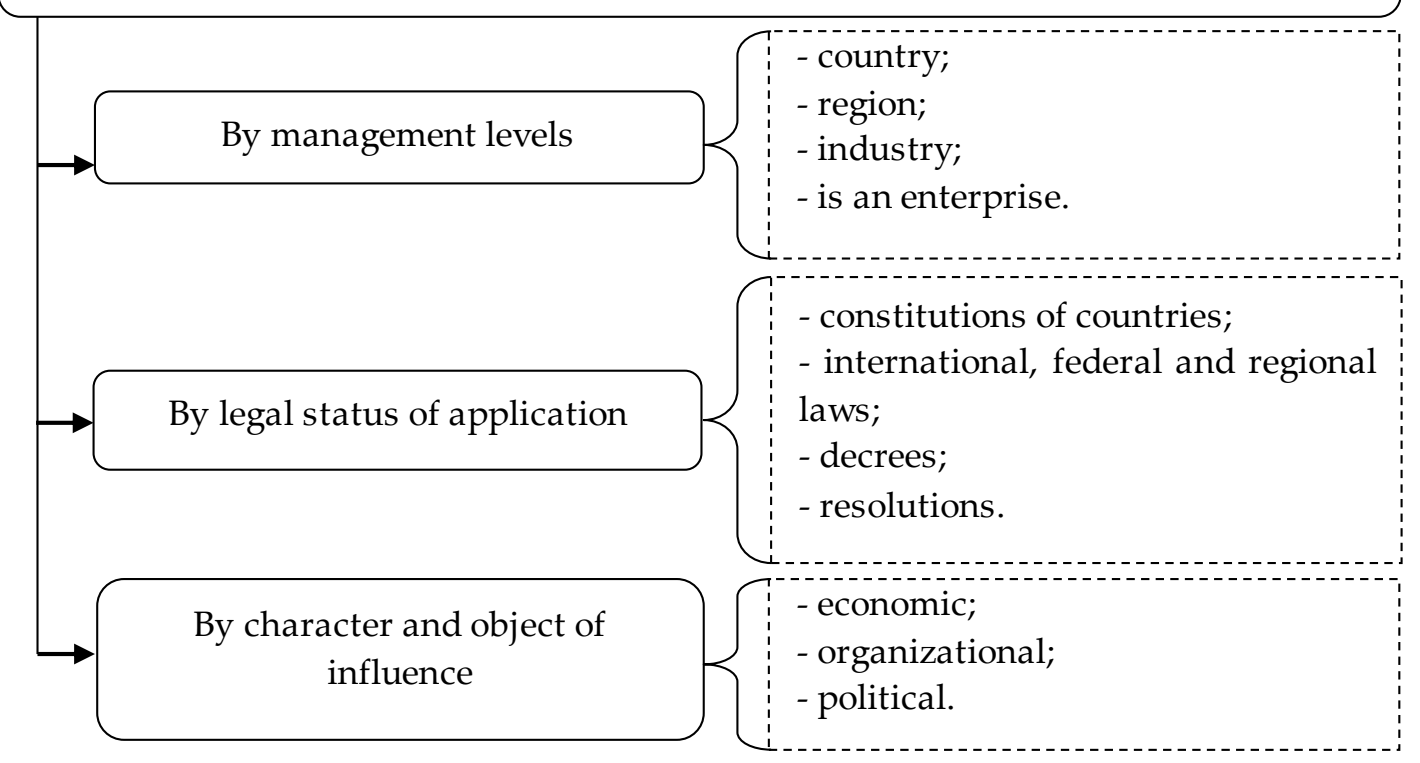

Fig. 2. Classification of instruments for the regulation of financial imbalances of endogenously oriented development. Source: by the author

Classification of instruments for the regulation of financial imbalances of endogenously-oriented development is characterized by the use of a wide range of measures for promoting sustainable development and is presented in Table. 1.

\begin{tabular}{|c|c|c|c|}
\hline \multirow{13}{*}{ 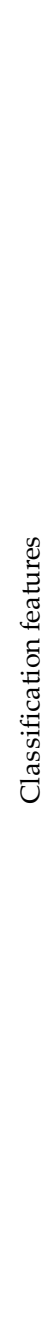 } & & Type of classification & Specifics \\
\hline & \multirow[b]{2}{*}{ 1) by subject: } & $\begin{array}{l}\text { tools to promote sustainable } \\
\text { development in the region }\end{array}$ & $\begin{array}{c}\text { incentive instruments aimed at the activities of economic entities } \\
\text { and regional authorities in all regions to achieve sustainable } \\
\text { development used by public authorities; }\end{array}$ \\
\hline & & $\begin{array}{l}\text { tools for motivating the } \\
\text { region's sustainable } \\
\text { development }\end{array}$ & $\begin{array}{l}\text { measures of internal activation of activity of economic entities in the } \\
\text { social, economic and environmental spheres of the region, aimed at } \\
\text { achieving sustainable development through the application of a } \\
\text { motivational approach to increasing the internal potential reserves } \\
\text { of a particular region used by regional authorities; }\end{array}$ \\
\hline & \multirow{4}{*}{$\begin{array}{l}\text { 2) in the direction of } \\
\text { stimulation: }\end{array}$} & investment and innovation & $\begin{array}{l}\text { activation measures based on investment in the development and } \\
\text { implementation of new technologies, processes and innovative } \\
\text { proposals to achieve sustainable development in the region; }\end{array}$ \\
\hline & & $\operatorname{tax}$ & $\begin{array}{l}\text { instruments for promoting the sustainable development of the } \\
\text { region, based on the levers of the tax system (taxes, payments, fees, } \\
\text { penalties, tax breaks and credits), and aimed at achieving the } \\
\text { sustainable development of the region; }\end{array}$ \\
\hline & & transfer & $\begin{array}{l}\text { incentive measures aimed at improving the financial situation in the } \\
\text { region and achieving sustainable development through the use of a } \\
\text { system of budgetary allocations (grants, subsidies, subsidies); }\end{array}$ \\
\hline & & institutional & $\begin{array}{l}\text { incentive measures implemented by state and regional authorities to } \\
\text { improve the financial situation in the region (permits, restrictions, } \\
\text { agreements, programs); }\end{array}$ \\
\hline & \multirow{3}{*}{$\begin{array}{l}\text { 3) the duration of the } \\
\text { stimulus event: }\end{array}$} & long term & $\begin{array}{l}\text { tools for promoting the sustainable development of the region, } \\
\text { which have been in use for over } 5 \text { years; }\end{array}$ \\
\hline & & medium term & sustainable development measures that last for 3 to 5 years; \\
\hline & & short term & $\begin{array}{l}\text { instruments for promoting the sustainable development of the } \\
\text { region, whose duration is limited to } 1 \text { to } 3 \text { years; }\end{array}$ \\
\hline & \multirow{3}{*}{ 4) by funding source: } & state & $\begin{array}{c}\text { sustainable development instruments financed by state or local } \\
\text { budgets, public funds, and state-owned enterprises; }\end{array}$ \\
\hline & & private & $\begin{array}{l}\text { incentive measures aimed at achieving sustainable development of } \\
\text { the region and funded by private entities of various organizational } \\
\text { forms and types; }\end{array}$ \\
\hline & & internal & $\begin{array}{l}\text { instruments for stimulating sustainable development of the region, } \\
\text { financed by intra-regional sources; }\end{array}$ \\
\hline
\end{tabular}




\begin{tabular}{|c|c|c|c|}
\hline \multirow{11}{*}{ 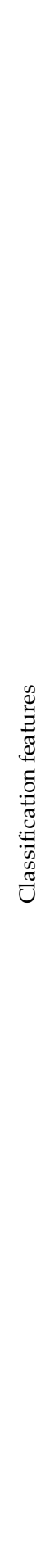 } & & Type of classification & Specifics \\
\hline & & external & $\begin{array}{c}\text { incentives for sustainable development in the region and funded } \\
\text { through national or interregional programs and agreements as well } \\
\text { as international organizations. }\end{array}$ \\
\hline & \multirow{3}{*}{$\begin{array}{l}\text { 5) tax instruments for } \\
\text { promoting sustainable } \\
\text { development: }\end{array}$} & tax scientific credit & $\begin{array}{c}\text { deducted from the taxable amount of monthly income of legal } \\
\text { entities carrying out R\&D expenses on research activities. The } \\
\text { purpose of the tool is to develop new technologies and translate } \\
\text { scientific achievements to achieve sustainable development in the } \\
\text { region. }\end{array}$ \\
\hline & & investment tax credit & $\begin{array}{l}\text { deduction from the taxable amount of monthly income of legal } \\
\text { entities engaged in innovative investing. The tool is aimed at } \\
\text { promoting innovation in the social, environmental and economic } \\
\text { spheres to achieve sustainable regional development. }\end{array}$ \\
\hline & & $\begin{array}{l}\text { tax preferences for high-tech } \\
\text { and environment-oriented } \\
\text { enterprises in the region }\end{array}$ & $\begin{array}{l}\text { on the territory of the region by partial exemption from taxation of } \\
\text { legal entities carrying out such activity. The tool will allow to } \\
\text { expand ecological products and services, ensure ecological balance, } \\
\text { achieve sustainable development of the region. }\end{array}$ \\
\hline & \multirow{2}{*}{$\begin{array}{l}\text { 6) transfer tool to } \\
\text { stimulate sustainable } \\
\text { development of the } \\
\text { region: }\end{array}$} & $\begin{array}{l}\text { direct subsidy to local } \\
\text { budgets for environmental } \\
\text { measures and regional } \\
\text { resource policy }\end{array}$ & $\begin{array}{l}\text { budgetary allocation from the State Budget of Ukraine for regions } \\
\text { with significant environmental problems, as needed. The purpose of } \\
\text { the instrument programs is to overcome environmental problems in } \\
\text { the regions of Ukraine and to promote the sustainable development } \\
\text { of the regions. }\end{array}$ \\
\hline & & $\begin{array}{l}\text { direct subsidy to regions } \\
\text { forced to sustain industrial } \\
\text { development }\end{array}$ & $\begin{array}{l}\text { program budget allocation from the State Budget of Ukraine to a } \\
\text { specific region, where purposefully adheres to industrial } \\
\text { development in order to preserve the social and environmental } \\
\text { sphere of the region. The main objective of the toolkit programs is to } \\
\text { compensate a specific region for slowing down industrial } \\
\text { development in order to rebalance the areas of the regional SEE } \\
\text { system.. }\end{array}$ \\
\hline & \multirow{2}{*}{$\begin{array}{l}\text { 7) investment- } \\
\text { innovative tools for } \\
\text { stimulating } \\
\text { sustainable } \\
\text { development of the } \\
\text { region: }\end{array}$} & $\begin{array}{l}\text { innovative investment in } \\
\text { regional science and } \\
\text { technology }\end{array}$ & $\begin{array}{l}\text { private and public investment in high technology, focused on } \\
\text { achieving sustainable development of the regional SEE system. The } \\
\text { tool is aimed at restoring ecological balance, achieving social justice } \\
\text { and ensuring the economic grow th of regions through the } \\
\text { implementation of high-tech investment projects. }\end{array}$ \\
\hline & & $\begin{array}{l}\text { innovations to restore the } \\
\text { primary qualities of the } \\
\text { region's resources used }\end{array}$ & $\begin{array}{l}\text { implementation of high-tech projects implemented by legal entities } \\
\text { in the region and related to the natural resources of the region. The } \\
\text { purpose of the incentive tool is to restore the natural resource } \\
\text { potential of the region, to ensure the suitability of the resources used } \\
\text { to achieve sustainable development of the region. }\end{array}$ \\
\hline & \multirow{2}{*}{$\begin{array}{l}\text { 8) institutional tools } \\
\text { for promoting } \\
\text { sustainable } \\
\text { development of the } \\
\text { region: }\end{array}$} & $\begin{array}{l}\text { state procurement of highly } \\
\text { efficient regional projects } \\
\text { and technologies in } \\
\text { environmental and social } \\
\text { terms }\end{array}$ & $\begin{array}{l}\text { defining the list of priority social-environmental projects, financing } \\
\text { them and implementing them in order to achieve sustainable } \\
\text { development of the region. The main purpose of the incentive tool is } \\
\text { to develop high-tech, energy-efficient, environmentally friendly and } \\
\text { socially-oriented production. }\end{array}$ \\
\hline & & $\begin{array}{l}\text { regional cross-border } \\
\text { cooperation in the field of } \\
\text { sustainable development }\end{array}$ & $\begin{array}{l}\text { cross-border regional cooperation in social, economic and } \\
\text { environmental spheres to achieve sustainable regional development. } \\
\text { This tool will enhance the cooperation of the regions of Ukraine with } \\
\text { the regions of neighboring countries in the social, economic and } \\
\text { environmental spheres of the region, contributing to the sustainable } \\
\text { development of the region. }\end{array}$ \\
\hline
\end{tabular}

Tab. 1. Classification of instruments for regulation of financial imbalances of endogenously oriented development. Source: is based on [4]

At the same time, the classification of instruments for regulating financial imbalances of endogenously-oriented development is used to achieve sustainable development of the regions within different policies to stimulate sustainable development of the regions, should ensure the competitive development of the economy, revitalization of the social sphere and ensure its environmental safety, as well as ensuring the environmental safety of the regions. At the same time, it is possible to achieve a high level of sustainable development of the regions only when the instruments for promoting sustainable development have a regional socio-ecological-economic effect of their application. 
The tools of regulation of financial imbalances of endogenously-oriented development of the regions, which are used to analyse the impact on the efficiency of development of regions at different stages of the economic cycle, can be classified into three main areas: administrative, organizationaleconomic and financial (Figure 3).

\begin{tabular}{|c|c|c|}
\hline \multicolumn{3}{|c|}{$\begin{array}{l}\text { The main directions of instruments of regulation of financial imbalances } \\
\text { of endogenously oriented development of regions }\end{array}$} \\
\hline Administrative & Organizational and economic & Financial \\
\hline $\begin{array}{l}\text { - Methodology for selecting } \\
\text { depressed regions for priority } \\
\text { financing. } \\
\text { - Improving the system of } \\
\text { relations "federal center - } \\
\text { regions". } \\
\text { - Regulations for the } \\
\text { establishment of special } \\
\text { economic regimes in certain } \\
\text { territories (special economic } \\
\text { zones, zones of special } \\
\text { socioeconomic regime of } \\
\text { nature management). } \\
\text { - Methodology to support the } \\
\text { improvement of regulation of } \\
\text { financial imbalances in } \\
\text { endogenously oriented } \\
\text { regional development. } \\
\text { - Creation of target corporate } \\
\text { structures for regulation of } \\
\text { financial imbalances of } \\
\text { endogenously oriented } \\
\text { development of regions. }\end{array}$ & $\begin{array}{l}\text { - Systematic analysis of } \\
\text { endogenous oriented regional } \\
\text { development. } \\
\text { - Creation of special economic } \\
\text { zones: industrial-industrial } \\
\text { type, technical- } \\
\text { implementation type, tourist- } \\
\text { recreational type, port zones. } \\
\text { - Programs of integrated } \\
\text { endogenous-oriented } \\
\text { development of regions. } \\
\text { - Methods for creating clusters } \\
\text { and technoparks. } \\
\text { - Development of a } \\
\text { methodology for activating the } \\
\text { processes of forming an } \\
\text { entrepreneurial and } \\
\text { innovative initiative. } \\
\text { - Definition of long-term rules } \\
\text { of investor relations. }\end{array}$ & $\begin{array}{l}\text { - System transfers of regions. } \\
\text { - Full financing of state } \\
\text { responsibilities to the } \\
\text { population of the regions. } \\
\text { - Methods of improving the } \\
\text { system of benefits for the } \\
\text { inhabitants of the regions. } \\
\text { - Flexible tax and pricing } \\
\text { policy for companies and } \\
\text { firms related to the activities } \\
\text { of city-forming enterprises } \\
\text { that produce products and } \\
\text { services that are important for } \\
\text { the development of regions. } \\
\text { - Distribution of investment } \\
\text { funds by region. } \\
\text { - Long-term programs to } \\
\text { support projects to improve } \\
\text { transport and logistics } \\
\text { infrastructure in the regions. }\end{array}$ \\
\hline
\end{tabular}

Fig. 3. The main directions of instruments of regulation of financial imbalances of endogenously oriented development of regions Source: by the author

Each direction of regulation of financial imbalances of endogenously oriented development of regions can have many modifications depending on what elements of distributive relations they contain. Each destination is responsible for a specific purpose in the form of assigned functions. The main areas of interaction are through financial instruments, thus influencing the different aspects of endogenously oriented regional development.

In the process of regulating the financial imbalances of endogenously-oriented regional development, it is proposed to concentrate efforts on the creation of special instruments, which include both the development of regulations defining the formation of new organizational forms and the practice of special types of transfers.

After all, regulation of financial imbalances of endogenously-oriented development of regions should be carried out by a system of specially organized measures of political, legal, social, financial, economic character, called (Figure 4). 


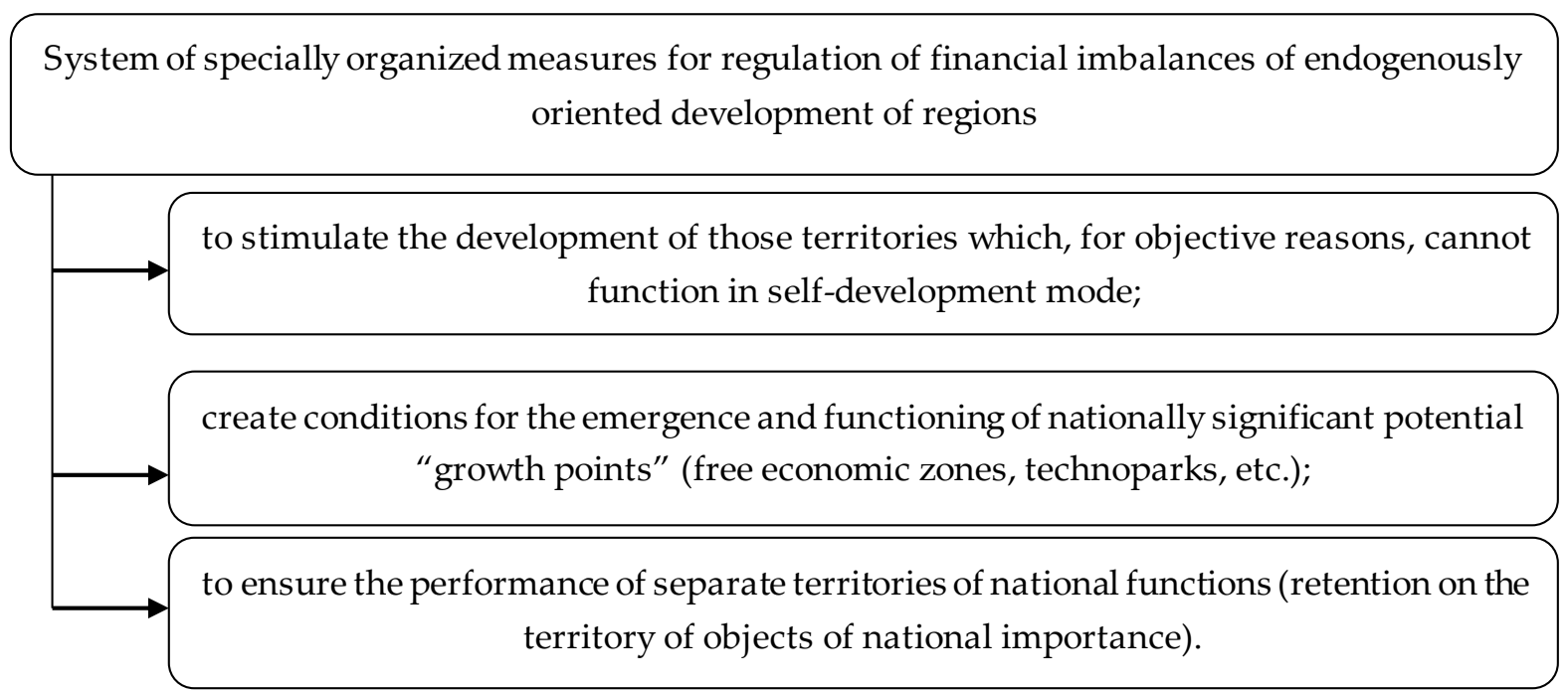

Fig. 4. System of specially organized measures for regulation of financial imbalances of endogenously oriented development of regions. Source: is based on [2]

It is obvious that the use of financial imbalances in the endogenously oriented development of the regions, both equalizes and stimulate subsidies, as well as subsidies and employ a comprehensive approach.

This means overcoming the traditional view of intergovernmental budgetary regulation as an auxiliary process that ensures the transfer of funds between budgets at different levels. It can be concluded that any relationship between state authorities and municipalities arising from the distribution of tax revenues, spending powers, and especially transfers, affects the interests of both parties and presupposes their harmonization [5].

In conditions of economic instability, problems related to ensuring the development of regions were actualized. Practice shows that more attention has traditionally been paid to the development of public policy that regulates the financial imbalances of regional development, as well as the search for legal, organizational and economic mechanisms.

However, the issues of regulating the financial imbalances of endogenously-oriented regional development are most acute at the local level, where a clear lack of tax and non-tax revenues to finance regional development is observed when using the current system of distribution of financial revenues. In such a situation, special importance is given to fiscal mechanisms for regulating municipal development.

\section{CONCLUSIONS}

The results of the study allow us to formulate the following conclusions:

1. Perspective directions of improvement of the system of regulation of financial imbalances of endogenously-oriented development of regions can be formed and practicing of the practice of providing system transfers to regions lagging behind in socioeconomic development, formation of special instruments of regulation of financial imbalances of regional development - target economic zones. An effective direction for improvement may be the creation of a corporation of regions within the territorial development of zones of special social-ecological regime of nature management. In this case, it is advisable to provide for the possibility of modifying the use of regulatory instruments at the stages of financial and economic crises and depression.

2. At the regional level, it is advisable to concentrate the efforts of the executive and legislative bodies on increasing the decentralized resources for financing the development of the territories. The process of formation of decentralized sources of realization of the perspective directions of development of regions raises efficiency of endogenously-oriented development of regions at once in several directions: first, an environment is created to form a system of investment projects capable of 
leading the region out of a state of depression; secondly, the conditions for effective development of significant investment inflows are formed, in particular at the expense of investors of national welfare, the personnel reserve is created through the implementation of global projects, the project basis of strategic development is expanded by increasing the number of developed and passed re-engineering projects of enterprises and structural restructuring, and financial resources are being accumulated to modernize the region's banking system in order to increase the share of long-term loans and to include regional banks in the system of large investment projects that can bring the productive forces of the region to a new level of development.

\section{REFERENCES}

[1] Shvetsov A.N. Improving the regional policy: concepts and practices. Krasand, Moscow, 2010. (in Russian)

[2] Gerasimchuk Z.V., Galushchak V.L. Policy area development problem areas: methodological principles of formation and implementation. Nadstyr'ia, Lutsk, 2006. (in Ukrainian)

[3] Varnalii Z.S., Mokii A.I., Novikova O.F. Regions of Ukraine: problems and priorities of socio-economic development: a monograph. Znannia Ukrainy, Kyiv, 2005. (in Ukrainian)

[4] Hura Ya.V. Instruments for stimulating sustainable development of Ukrainian regions. Scientific Bulletin of the Academy of Municipal Administration. Series: Management, 3 (2012), 324-331. Available at: http://www.irbis-nbuv.gov.ua/cgi-

bin/irbis_nbuv/cgiirbis_64.exe?I21DBN=LINK\&P21DBN=UJRN\&Z21ID=\&S21REF=10\&S21CNR=20\&S2 $1 \mathrm{STN}=1 \& S 21 \mathrm{FMT}=\mathrm{ASP}$ _meta\&C21COM=S\&2_S21P03=FILA=\&2_S21STR=Nvamu_upravl_2012_3_44 (in Ukrainian)

[5] Levina V.V. Effectiveness of inter-budget regulation at regional level. Finance and Credit, 15 (2011), 52 58. (in Russian)

Address: Taras Kloba, Solomiia Kloba, Institute of Regional Research named after M.I. Dolishniy of the National Academy of Sciences of Ukraine, 4, Kozelnytska Str., Lviv, 79026, Ukraine;

E-mail: taras@klioba.com, solomiia@klioba.com.

Received: 13.08.2019; revised: 22.10.2019.

Кльоба Тарас, Кльоба Соломія. Обгрунтування дієвих інструментів регулювання фінансових дисбалансів ендогенно-орієнтованого розвитку регіонів України. Журнал Прикарпатського університету імені Василя Стефаника, 6 (3-4) (2019), 46-54.

У статті розглянуті інструменти, які рекомендовані для регулювання фінансових дисбалансів ендогенно-орієнтованого розвитку регіонів України як складова частина механізму управдіння регіональною економікою, а також вивчені шляхи регулювання регіональних соціально-економічних процесів в кризових умовах. Визначено основні принципи відбору інструментів регудювання фінансових дисбалансів ендогенно-орієнтованого розвитку регіонів. Розглянуто класифікацію інструментів регулювання фінансових дисбалансів ендогенно-орієнтованого розвитку. Проаналізовано основні інструменти, які використовуються для забезпечення розвитку регіонів і муніципальних утворень: правові; пов'язані з розробкою відповідних стратегій і програм; засновані на реалізації міжмуніципального співробітництва; фінансові. 
Досліджено три основні напрямки інструментів регулювання фінансових дисбалансів ендогенно-орієнтованого розвитку регіонів, що застосовуються 3 метою аналізу впливу на ефективність розвитку регіонів на різних етапах економічного циклу. Обгрунтовано систему спеціально організованих заходів регулювання фінансових дисбалансів ендогенно-орієнтованого розвитку регіонів.

В сучасних умовах велика увага приділяється проблемам регулювання фінансових дисбалансів ендогенно-орієнтованого розвитку регіонів України, реалізація якого потребує спеціальних інструментів. Запропоновано цілісне уявлення системного механізму регулювання фінансовими дисбалансами ендогенно-орієнтованого розвитку регіонів. Адже, забезпечення ендогенноорієнтованого розвитку регіонів в сучасних умовах функціонування економіки України вимагає реалізації стратегії соціально-економічних перетворень, які будуть спрямовані на зміну фінансових дисбалансів розвитку регіонів та механізмів їх реалізації. Ендогенно-орієнтований розвиток регіонів означає підвищення рівня подолання несприятливих соціальних, економічних і екологічних ризиків та тенденцій, із спроможністю регіонів забезпечувати фінансові дисбаланси, саморегулювання, самовдосконалення із максимальним використанням внутрішніх, а також зовнішніх позикових ресурсів для задоволення потреб населення регіонів.

Ендогенно-орієнтований розвиток регіонів обумовдюється визначенням інструментів регулювання фінансових дисбалансів регіонів та виявлення умов щодо їх досягнення, які є похідними для забезпечення ендогенно-орієнтованого розвитку регіонів в цілому.

Ключові слова: основні принципи відбору інструментів регулювання, інструменти регулювання фінансових дисбалансів, класифікація інструментів регулювання, основні напрямки інструментів регулювання. 